\title{
DNA topoisomerase $\| \alpha$ expression and the response to primary chemotherapy in breast cancer
}

\author{
G MacGrogan*,', P Rudolph², I de Mascarel', L Mauriac', M Durand', A Avril', JM Dilhuydy', J Robert', \\ S Mathoulin-Pélissier', V Picot', A Floquet', G Sierankowski' and JM Coindre' \\ 'Departments of Pathology, Oncology, Surgery, Radiotherapy, Biochemistry and Biostatistics, Institut Bergonié, 229 Cours de l'Argonne, 33076 Bordeaux \\ cedex France; ${ }^{2}$ Department of Pathology and Lymph Node Registry appointed by the German Association of Pathologists, University of Kiel, Department \\ of Pathology, Michaelisstr. II, D-24 I05 Kiel, Germany
}

The $\alpha$ isoform of Topoisomerase $\| \alpha($ Topo $\| \alpha$ ) is a proliferation marker as well as a target for several chemotherapeutic agents such as anthracyclines. In vitro studies have demonstrated the relationship between the Topo $\| \alpha$ expression level and chemosensitivity of target cancer cells. To verify this effect in vivo, we selected 125 patients presenting with $T_{2}>3 \mathrm{~cm}$ and $T_{3} N_{0-1} M_{0}$ breast tumours who were treated by six cycles of primary chemotherapy, including epirubicin before any surgery. Therapy response was assessed by clinical and X-ray mammogram measurements of tumour shrinkage. The pretherapeutic core biopsies were immunostained with a monoclonal antibody (Ki-S7) against Topo Il $\alpha$. Ki-S7 positivity ranged from 0 to 50\% (median, I5\%). A high percentage of Ki-S7positive cells ( $>$ 15\%) was associated with tumour regression under chemotherapy $(O R=2.88, \mathrm{Cl}:$ : $1.3-6.4, P=0.004)$. Ki-S7 further emerged as an independent predictor of tumour regression $(\mathrm{OR}=3.34, \mathrm{Cl}$ : $1.41-7.93, P=0.006)$, together with tumour size of less than $40 \mathrm{~mm}(\mathrm{OR}=3.82, \mathrm{Cl}: \quad 1.58-9.25, P=0.002)$ and negative oestrogen receptor $(E R)$ status $(O R=3.35, C l: 1.43-7.86$, $P=0.005)$, in a multivariate analysis including tumour size, SBR grade, ER and PR status, Ki-67, p53 and Her-2/neu. Our clinical results confirm in vitro data on the relationship between Topo $\| \alpha$ expression and tumour chemosensitivity and thus may have important practical implications.

British Journal of Cancer (2003) 89,666-67I. doi:I0.1038/sj.bjc.660II85 www.bjcancer.com

(c) 2003 Cancer Research UK

Keywords: Topoisomerase Il $\alpha$; breast cancer; primary chemotherapy; anthracyclines; Her-2/neu

Topoisomerase II $\alpha$ (Topo II $\alpha$ ) is a vital nuclear DNA-binding enzyme that controls and modifies the topologic states of DNA (Berger et al, 1996) by combining nuclease, helicase and ligase activities. Topo II $\alpha$ reduces DNA supercoiling and twisting by creating a double-strand nick that enables the passage of a second DNA double-strand through the break and subsequent religation of the cleaved DNA strand. Topo II $\alpha$ is the specific target of several chemotherapeutic agents, including anthracyclines. These drugs bind to Topo II $\alpha$-DNA complexes and inhibit the religation step, which results in stabilisation of the DNA double-strand breaks that are thought to induce apoptosis (Kellner et al, 2002).

It has been previously demonstrated in vitro that the sensitivity of tumour cell lines to various Topo II $\alpha$ poisons, such as anthracyclines or etoposide, depends on the level of Topo II $\alpha$ expression (Gudkov et al, 1993; Asano et al, 1996a, b; Vassetzky et al, 1996; Withoff et al, 1996a, b; Zhou et al, 1999; Stacey et al, 2000 ). Moreover, the TOP $2 \alpha$ gene being located at $17 q 12-21$ close to the Her-2/neu oncogene, coamplification of the Her-2/neu and TOP $2 \alpha$ genes was observed in $44 \%$ of breast cancers, whereas the TOP $2 \alpha$ was deleted in another $42 \%$ (Jarvinen et al, 2000). It also appears that Topo II $\alpha$ expression is often correlated to Her-2/neu overexpression in breast carcinoma. This complex relationship between the two genes may explain the altered sensitivity to

*Correspondence: Dr G MacGrogan, Laboratoire d'Anatomie Pathologique, Institut Bergonié, 229, Cours de l'Argonne, 33076 Bordeaux cedex, France; E-mail: macgrogan@bergonie.org

Received 2 December 2002; revised 7 May 2003; accepted 5 June 2003 anthracyclines of Her-2/neu-amplified breast carcinomas (Bitran et al, 1996; MacGrogan et al, 1996a; Niskanen et al, 1997; Clahsen et al, 1998; Jarvinen et al, 1998; Paik et al, 1998; Thor et al, 1998; Vincent-Salomon et al, 2000). Most previous studies regarding the effect of Topo II $\alpha$ poisons in relation to the cellular level of Topo II $\alpha$ expression were either performed in vitro or on breast tumour fragments without analysis of the direct in vivo effect (Gudkov et al, 1993; Asano et al, 1996a, b; Vassetzky et al, 1996; Withoff et al, 1996a, b; Zhou et al, 1999; Stacey et al, 2000). The aim of our study was to analyse this effect in a series of breast carcinoma patients treated by primary chemotherapy, and to study the relationship between Topo II $\alpha$ and Her-2/neu in this setting. To this end, we investigated the predictive and prognostic values of Topo II $\alpha$ expression by immunohistochemical detection of the enzyme in breast tumour core biopsies from patients with large operable invasive cancers of the breast treated by primary chemotherapy including epirubicin. Furthermore, we studied the relationship between Topo II $\alpha$ expression and different factors modifying tumour chemosensitivity, such as Her-2/neu, hormonal receptor, Ki-67 and p53 immunohistochemical detection.

\section{MATERIALS AND METHODS}

\section{Patients}

Immunohistochemical detection of Topo II $\alpha$ was performed on tumour core biopsies from 128 patients with primary metastasisfree operable breast cancers, larger than $3 \mathrm{~cm}$. These patients 
belonged to the neoadjuvant chemotherapy arm of a randomised phase III trial that compared modified radical mastectomy followed by adjuvant chemotherapy to neoadjuvant chemotherapy followed by adapted locoregional treatment in large operable breast tumours. The clinical trial was conducted at Bergonié Institute from January 1985 to April 1989 and included a total of 272 patients. The chemotherapy regimens used in the trial comprised three courses of epirubicin, vincristine and methotrexate (EVM) followed by three courses with mitomycin C, thiotepa and vindesin (MTV), for more details see Mauriac et al (1999). All the biopsies analysed in the present study came from the primary chemotherapy, arm of the clinical trial. After completion of the six courses of chemotherapy, clinical examination and mammography were used to assess tumour regression. Subsequent locoregional treatment depended on the extent of tumour regression: radiotherapy was applied exclusively in case of complete regression, conservative surgery with axillary node dissection followed by radiotherapy were performed when tumour regression was incomplete with residual tumour measuring less than $2 \mathrm{~cm}$ in diameter; the remaining patients underwent mastectomy.

The predictive and prognostic value of the immunohistochemical detection of oestrogen and progesterone receptors, p53, Her-2/ $n e u$, and Ki-67 (antibody: Mib-1), had been analysed previously on the same cohort (MacGrogan et al, 1996a) and served as reference data for the current study.

\section{Immunohistochemical assay}

The pretherapeutic tumour core biopsies fixed in Holland's fluid and embedded in paraffin were retrieved from the files of Institute Bergonié. Five $\mu \mathrm{m}$ thick were cut, mounted on silane-coated slides and routinely processed. Antigen retrieval was obtained by heating the sections immersed in $0.01 \mathrm{~m}$ citrate buffer, $\mathrm{pH} 6.0$, in a pressure cooker for $20 \mathrm{~min}$. The sections were then incubated for $60 \mathrm{~min}$ with Ki-S7, a monoclonal antibody specific for Topo II $\alpha$. Ki-S7 was elaborated after immunising Balb/c mice with crude L428 nuclear extracts, performing mouse splenic/myeloma hybridoma cell cultures and purifying cell culture supernatants on a G-Sepharose 4 Fast Flow column (Pharmacia LKB; Freiburg, Germany) (Kellner et al, 1997). Ki-S7 specificity for Topo II $\alpha$ was verified in immunoprecipitation and Western blot experiments. Ki-S7 immunoreactivity on archival paraffin-embedded tumour material using an antigen retrieval procedure was also controlled (Kellner et al, 1997).

Ki-S7 was used undiluted as a lyophilised cell culture supernatant reconstituted with $5 \mathrm{ml} \mathrm{H}_{2} \mathrm{O}$. The immunoreaction was enhanced by means of an avidin - streptavidin-biotin peroxidase technique (Strept ABC complex/HRP Duet kit, Dako, France) with diaminobenzidine as a chromogen. MCF7 cell pellets with a high percentage of cells in G2 phase were fixed in Holland's fluid and embedded in paraffin to serve as positive controls in each series assayed immunohistochemically for Topo II $\alpha$ expression. Negative controls consisted of normal nonhyperplastic epithelial cells present in terminal ductal lobular units in the breast core biopsies.

All slides were read by one of the authors (GMG) who was blinded to the clinical results. Only unequivocal nuclear staining of invasive tumour cells was scored as positive (Figure 1). The percentage of positive tumour cells per tissue section was determined semiquantitatively in $5 \%$ steps.

\section{Statistical analysis}

The threshold used for p53 positivity was $1 \%$; for IHC-ER and IHC-PR positivity, the threshold was $10 \%$. These optimal thresholds have already been determined in previous studies to be the most informative for clinical outcome (de Mascarel et al, 1995; MacGrogan et al, 1995; MacGrogan et al, 1996a, b). A Ki-67 (Mib1) index of $40 \%$ was arbitrarily chosen as a threshold, at the
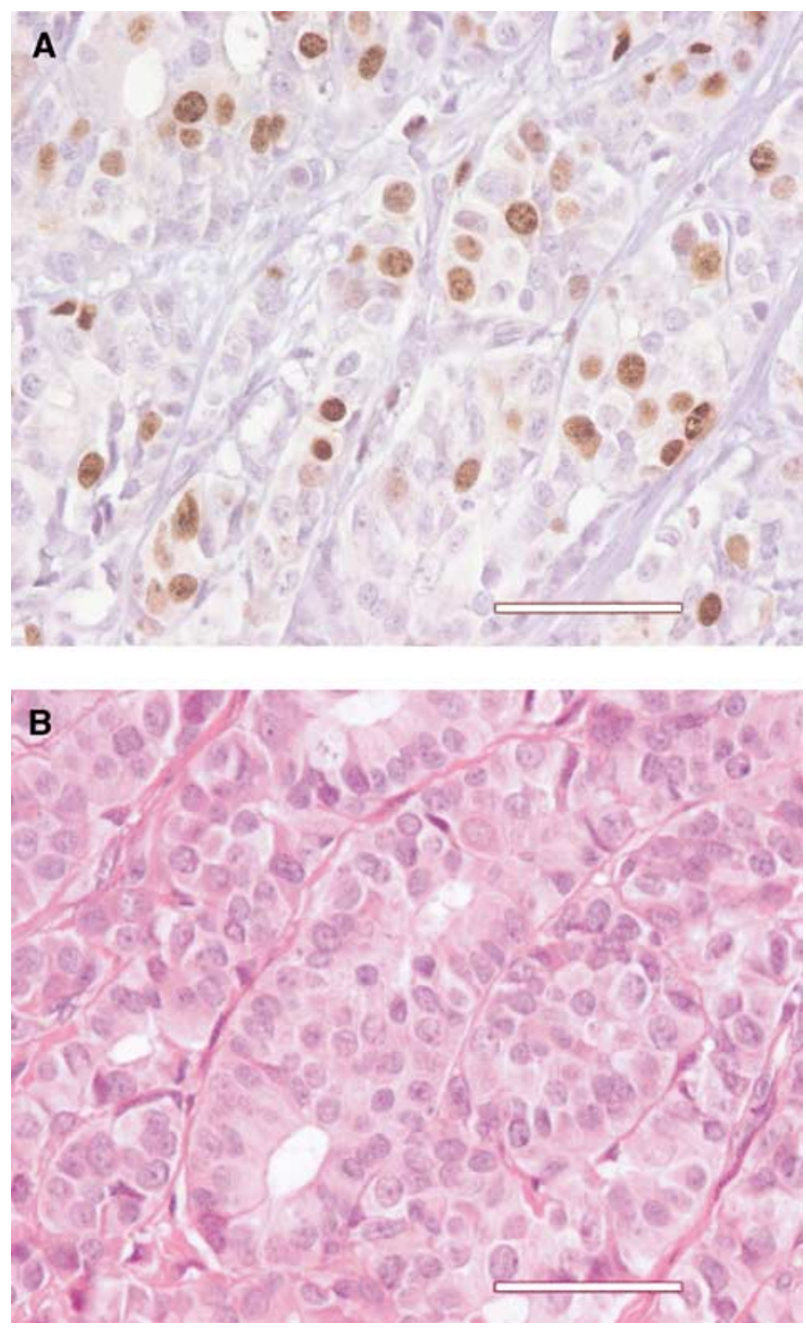

Figure I Nuclear immunostaining (Topo Il $\alpha$ ) of $25 \%$ cells in a Holland's bouin-fixed paraffin-embedded microbiopsy of an invasive ductal carcinoma NOS using monoclonal antibody Ki-S7 specific for topoisomerase $\| \alpha(\mathbf{A})$. Haematoxylin eosin saffron stain of the same case (B). Scale bar $=50 \mu \mathrm{m}$.

beginning of the study, to differentiate highly proliferating tumours. This Ki-67 threshold had been chosen in our previous study on the same group (MacGrogan et al, 1996a), because it corresponded to the 75th percentile of Ki-67 expression in the series. Furthermore, $10 \%$ of positive invasive cancer cells with a moderate to strong intensity of staining was chosen for the Her2neu positivity threshold (Slamon et al, 2001). Finally, the median values of patients' ages and tumour sizes were chosen as cutoff points for the statistical analysis.

The $\chi^{2}$ test was used to investigate the significance of the relationship between Ki-S7 and the different immunohistochemical factors previously studied as well as the histological Scarff Bloom and Richardson (SBR) grade. The relation between Ki-S7 and the patient's age as well as tumour size was analysed by Student's $t$-test. A Kendall $\tau$ rank correlation test was performed to study the relationship between Ki-S7 and Ki-67, considering them as continuous variables.

The clinical size of the tumours was assessed before treatment, before the second and fourth courses of chemotherapy and after the sixth. A univariate analysis studying the relationship between tumour regression and the different factors was performed, using the $\chi^{2}$ test. Reciprocal influence among the different predictive factors was determined by multivariate analysis using a logistic 
regression test for multiple proportional hazards. The variable to predict was tumour regression $\geqslant 50 \%$, including complete tumour regression. To evaluate the predictive impact of Ki-S7 expression in this series, a first logistic regression model was performed (model 1), including all previously analysed factors without Ki-S7 (MacGrogan et al, 1996a). A second logistic regression model was then performed, after adding Ki-S7 (model 2). All factors were included in the logistic regression analyses, irrespective of their $P$ value by univariate analysis; but only those with a $P$-value $\leqslant 1 \%$ were retained in the final models.

The log-rank test using the Kaplan-Meier method was also used to study the relationship between KiS-7 and prognosis expressed as a 5-year probability of survival. Patient follow-up was carried out quarterly for 2 years, twice a year and finally yearly. For overall survival (OS), the survival duration was calculated from the randomisation date to death, or the date they were last known alive. All causes of death were considered as events. For metastasis-free interval (MFI) and disease-free interval (DFI), time to failure was computed from the randomisation date until metastasis or relapse, or the date they were last known to be disease-free, respectively. The median follow-up of patients in this series was 142 months, range 101-172 months.

Univariate and multivariate analyses (logistic regression model) were performed using version 10.0 of SPSS software.

\section{RESULTS}

Invasive carcinoma cells were present in 125 out of 128 biopsies; three core biopsy paraffin blocks contained no residual tumour material after tissue sectioning for histological diagnosis and analysis of the other immunohistochemical factors in the series, and the corresponding cases were excluded from the analysis. Patients' age in this series ranged from 31 to 70 years (mean: 53, median: 55). The mean and median tumour sizes were 43.2 and $40 \mathrm{~mm}$, respectively (range: $20-80 \mathrm{~mm}$ ). The majority of tumours in this series were invasive ductal carcinomas of no special type
$(115,92.2 \%)$, followed by invasive lobular carcinomas $(9,7.2 \%)$ and one mucous carcinoma $(0.6 \%)$.

\section{Ki-S7 expression in the series}

Ki-S7 positivity ranged from 0 to $50 \%$ with a median value of $15 \%$ positive tumour cells. $15 \%$ was consequently chosen as the threshold value between low $(\leqslant 15 \%)$ and high $(>15 \%)$ Topo II $\alpha$ expression.

\section{Relationship between Ki-S7 and other parameters (Table 1)}

Ki-S7 was positively associated with SBR grade and p53 expression $\left(P=1 \times 10^{-6}\right.$. and 0.03 , respectively) and negatively with the immunoexpression of ER and $\mathrm{PR}(P=0.007$ and 0.03 , respectively). No significant association was found between Ki-S7 and Her-2/neu or tumour size (Table 1).

Ki-S7 and Ki-67 were strongly positively correlated $(\tau=0.46$, $\left.P<10^{-3}\right)$ and associated $\left(P=4 \times 10^{-7}\right)$, considering them as continuous or dichotomous variables, respectively.

\section{Predictive and prognostic values of Ki-S7}

High expression of Ki-S7 ( $>15 \%)$ was associated with tumour regression $\geqslant 50 \%$ including complete tumour regression after six courses of chemotherapy $(\mathrm{OR}=2.88, \mathrm{CI}: 1.3-6.4, P=0.004)$ by univariate analysis (Table 2). The median Ki-S7 value was higher in the good response group (tumour regression $\geqslant 50 \%$ and complete tumour regression) compared to the poor response group (tumour regression $<50 \%$, tumour stabilisation and progression), 20 and $15 \%$, respectively. To evaluate the predictive impact of $\mathrm{Ki}-\mathrm{S} 7$ in this series, a first stepwise logistic regression model was performed with all the factors that had been previously analysed in the series, that is, clinical tumour size, SBR grade, IHCER, IHC-PR, Ki-67, p53 and Her-2/neu (Table 3, model 1). In this model, clinical tumour size less than $40 \mathrm{~mm}$, negative IHC-ER status and high expression of $\mathrm{Ki}-67(>40 \%)$ were found to be

Table I Relationship between Ki-S7 expression and classical and immunohistochemical markers

\begin{tabular}{|c|c|c|c|c|c|c|}
\hline \multirow[b]{2}{*}{ Variables } & \multirow[b]{2}{*}{ Total $^{\mathbf{a}}$} & \multirow[b]{2}{*}{ No. ${ }^{b}$} & \multirow[b]{2}{*}{ (\%) } & \multicolumn{3}{|c|}{ Univariate model } \\
\hline & & & & Odd ratios & $95 \% \mathrm{Cl}^{\mathrm{c}}$ & $P$ \\
\hline \multicolumn{7}{|l|}{ Tumour size } \\
\hline$\leqslant 40 \mathrm{~mm}$ & 69 & 28 & 40.6 & & & \\
\hline$>40 \mathrm{~mm}$ & 55 & 28 & 50.9 & 1.52 & $0.70-3.31$ & 0.25 \\
\hline \multicolumn{7}{|c|}{ Histologic SBR grade } \\
\hline Grade I & 25 & 4 & 16.0 & & & \\
\hline Grade 2 & 71 & 29 & 40.8 & 3.63 & $|.02-| 4.0 \mid$ & 0.024 \\
\hline Grade 3 & 29 & 24 & 82.8 & 4.87 & $2.16-11.01$ & $1 \times 10^{-6}$ \\
\hline \multicolumn{7}{|l|}{ P53 } \\
\hline 0 & 89 & 36 & 40.4 & & & \\
\hline$\geqslant 1 \%$ & 34 & 21 & 61.8 & 2.38 & $0.98-5.80$ & 0.034 \\
\hline \multicolumn{7}{|l|}{ IHC-ER } \\
\hline$<10 \%$ & 41 & 26 & 63.4 & & & \\
\hline$\geqslant 10 \%$ & 82 & 31 & 37.8 & 0.35 & $0.15-0.82$ & 0.007 \\
\hline \multicolumn{7}{|l|}{ IHC-PR } \\
\hline$<10 \%$ & 50 & 29 & 58 & & & \\
\hline$\geqslant 10 \%$ & 71 & 27 & 38 & 0.44 & $0.20-0.99$ & 0.03 \\
\hline \multicolumn{7}{|l|}{ Her2-neu ${ }^{d}$} \\
\hline Negative & 102 & 46 & 45.1 & & & \\
\hline Positive & 20 & 9 & 45 & 1.00 & $0.34-2.87$ & 0.99 \\
\hline \multicolumn{7}{|l|}{$\mathrm{KI}-67$} \\
\hline$\leqslant 40 \%$ & 97 & 33 & 34 & & & \\
\hline$>40 \%$ & 27 & 24 & 88.9 & 15.52 & $4.01-70.18$ & $4 \times 10^{-7}$ \\
\hline
\end{tabular}


Table 2 Factors associated with tumour regression $\geqslant 50 \%$, including complete tumour regression after six cycles of primary chemotherapy among 125 patients: univariate analysis

\begin{tabular}{|c|c|c|c|c|c|}
\hline \multirow[b]{2}{*}{ Variables (total) } & \multirow[b]{2}{*}{ Total } & \multirow[b]{2}{*}{ No. $^{a}$} & \multicolumn{3}{|c|}{ Univariate model } \\
\hline & & & $\mathbf{O} \mathbf{R}^{\mathbf{b}}$ & $95 \% \mathrm{Cl}^{\mathrm{c}}$ & $P$ \\
\hline \multicolumn{6}{|l|}{ Age (years) } \\
\hline$\leqslant 55$ & 65 & 32 & & & \\
\hline$>55$ & 60 & 23 & 0.64 & $0.30-1.39$ & 0.220 \\
\hline \multicolumn{6}{|l|}{ Clinical tumour size } \\
\hline$>40 \mathrm{~mm}$ & 55 & 17 & & & \\
\hline$\leqslant 40 \mathrm{~mm}$ & 69 & 37 & 2.58 & $1.16-5.83$ & 0.011 \\
\hline \multicolumn{6}{|l|}{ Histologic SBR grade } \\
\hline Grade I & 25 & 9 & & & \\
\hline Grade 2 & 71 & 29 & 1.23 & $0.43-3.51$ & 0.67 \\
\hline Grade 3 & 29 & 17 & 2.52 & $0.73-8.85$ & 0.09 \\
\hline \multicolumn{6}{|l|}{ ER } \\
\hline$\geqslant 10 \%$ & 82 & 26 & & & \\
\hline$<10 \%$ & 41 & 27 & 4.15 & $1.75-9.99$ & $<10^{-3}$ \\
\hline \multicolumn{6}{|l|}{ PR } \\
\hline$\geqslant 10 \%$ & 71 & 27 & & & \\
\hline$<10 \%$ & 50 & 25 & 1.63 & $0.73-3.63$ & 0.190 \\
\hline \multicolumn{6}{|l|}{ Her2-neu ${ }^{d}$} \\
\hline Negative & 102 & 41 & & & \\
\hline Positive & 20 & 11 & 1.82 & $0.63-5.30$ & 0.221 \\
\hline \multicolumn{6}{|l|}{$\mathrm{Ki}-67$} \\
\hline$\leqslant 40 \%$ & 97 & 36 & & & \\
\hline$>40 \%$ & 27 & 18 & 3.39 & $1.27-9.21$ & 0.006 \\
\hline \multicolumn{6}{|l|}{ Ki-S7 } \\
\hline$\leqslant 15 \%$ & 68 & 22 & & & \\
\hline$>15 \%$ & 57 & 33 & 2.88 & $1.3-6.4$ & 0.004 \\
\hline \multicolumn{6}{|l|}{ P53 } \\
\hline 0 & 89 & 36 & & & \\
\hline$\geqslant 1 \%$ & 34 & 17 & 1.47 & $0.62-3.51$ & 0.339 \\
\hline
\end{tabular}

${ }^{\mathrm{a}}$ \#:number of patients with tumour regression $\geqslant 50 \%$, including complete tumour regression after six cycles of primary chemotherapy. ${ }^{\mathrm{b}} \mathrm{OR}=$ odd ratios. $^{\mathrm{c}} 95 \mathrm{Cl}=95 \%$ confidence interval. ${ }^{\mathrm{d}} \mathrm{Her} 2$-neu positive cases were those with $10 \%$ or more positive tumour cells with a moderate or strong intensity of staining, Her2-neu negative cases were all the other cases.

Table 3 Factors associated with tumour regression $\geqslant 50 \%$, including complete tumour regression after six cycles of primary chemotherapy among 125 patients: multivariate analyses (model I: factors identified in MacGrogan et al, 1996a; model 2: with new factor, Ki-S7)

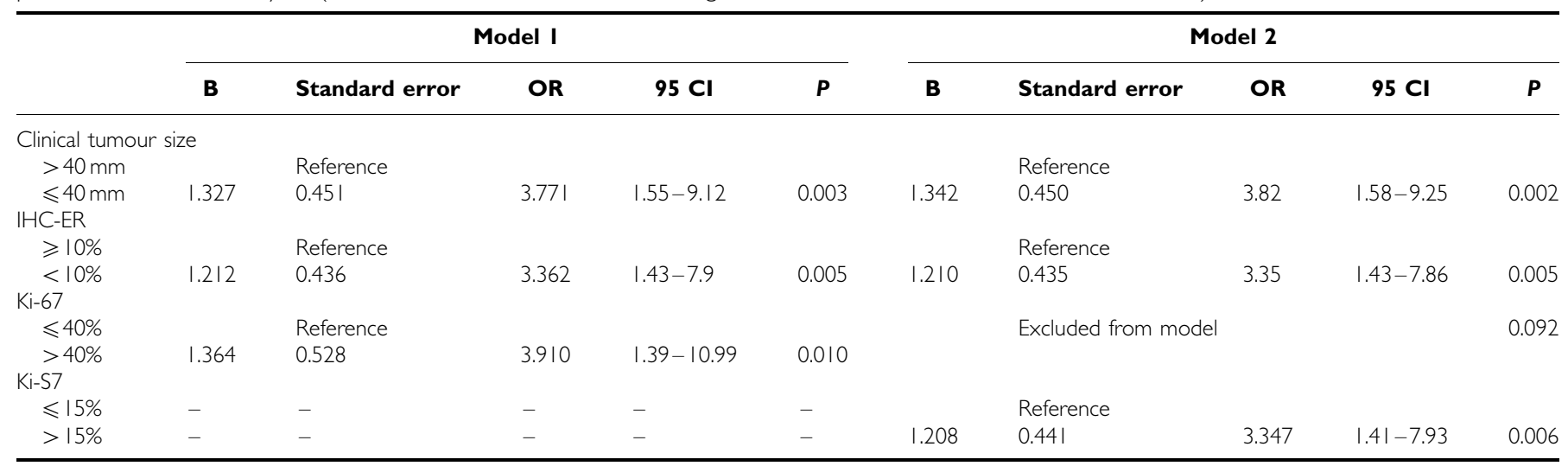

Each of the odds ratios is adjusted for all other variables in the table. $\mathrm{OR}=$ odd ratio. $95 \mathrm{Cl}=95 \%$ confidence interval.

independent predictive factors for tumour regression. When Ki-S7 was added (Table 3, model 2), independent predictive factors were clinical tumour size, IHC-ER and Ki-S7. Ki-67 expression was no longer considered an independent predictive factor for tumour regression in this second model $(P=0.092)$.

Considering the impact of concurrent Topo II $\alpha$ and Her-2/neu overexpression on tumour chemosensitivity described in the literature, the association of these two proteins was analysed in relation to tumour regression, but no significant correlation was found either by univariate or multivariate analysis.

By univariate analysis, no statistically significant relationship was found between Ki-S7 and DFI, MFI or OS (results not shown).

\section{DISCUSSION}

Previous studies, showing a relationship between the intracellular level of Topo II $\alpha$ and tumour chemosensitivity, were mainly based on in vitro experiments analysing the efficacy of other Topo II $\alpha$ inhibitors in various tumour cell lines, in particular etoposide (Gudkov et al, 1993; Asano et al, 1996a, b; Vassetzky et al, 1996; Withoff et al, 1996a, b; Stacey et al, 2000). In the current study, we have demonstrated for the first time a significant direct in vivo correlation between the level of Topo II $\alpha$ expression and breast cancer response to anthracycline-based chemotherapy. This result argues in favour of the concept that the efficacy of Topo II $\alpha$ 
670

poisons depends on the quantity of stabilised cleavable complexes, which in turn relates to the cellular expression and activity of Topo $\mathrm{II} \alpha$ (Kellner et al, 2002).

Jarvinen et al, (1998) found no significant correlation between Topo II $\alpha$ expression in primary breast tumours and the regression of metastases after chemotherapy in patients with advanced breast cancer treated with first-line epirubicin. The discrepancy between their results and ours may be attributable to different Topo II $\alpha$ contents in primary tumours and their metachronous metastases Indeed, in a series of 13 breast tumours, the same group subsequently showed some degree of variability between the Topo II $\alpha$ gene status of the primary breast tumour and that of its metastases by means of fluorescent in situ hybridisation (FISH) and chromogenic in situ hybridisation (CISH) (Tanner et al, 2001). Finally it is conceivable that due to intervening acquisition of drug-resistance mechanisms (Giesler et al, 2002), the effect of Topo II $\alpha$ inhibitors may be different in primary tumours and their corresponding asynchronous metastases, especially if an adjuvant protocol comprising a Topo II $\alpha$ inhibitor had previously been applied.

In line with the proliferation-specific expression of Topo II $\alpha$ (Kellner et al, 1997, 2002), we observed a highly significant correlation between $\mathrm{Ki}-\mathrm{S7}$ and $\mathrm{Ki}-67$, which was also reported by others (Depowski et al, 2000; Rudolph et al, 1999a; Tuccari et al, 1993), in addition to a strong link between the number of Topo II $\alpha$-expressing cells and the S-phase fraction of the cell cycle (Jarvinen et al, 1996; Sandri et al, 1996a). Given the known association between high tumour cell proliferation and chemosensitivity (Tannock, 1978; Belembaogo et al, 1992; O'Reilly et al, 1992), one might suspect the observed therapy response to be related to the proliferative activity of the tumours. Indeed, when we previously investigated the predictive value of various immunohistochemical factors in the same cohort (MacGrogan et al, 1996a), Ki-67 came out as an independent predictive factor for the therapy response in the multivariate analysis. After inclusion of Ki-S7 into the logistic regression model, however, Ki-67 lost its statistical significance. This suggests that Topo II $\alpha$ expression may have an impact on the responsiveness of tumours to cytotoxic therapy beyond its association with tumour cell proliferation, which is likely related to an increased sensitivity to the Topo II $\alpha$ inhibitory component of the treatment protocol, that is, epirubicin (Kellner et al, 2002). It is not possible to reproduce in vitro experiments identically in vivo because no current therapy protocol for breast cancer consists of a monotherapy with Topo II $\alpha$ inhibitors. It would nevertheless be difficult to explain the predictive superiority of Ki-S7 compared with Ki-67 than by a higher availability of substrate for the anthracycline component of the therapy regimen (Kellner et al, 2002). It is true that the assessment of the immunopositive cell fraction does not allow conclusions as to the protein content of individual cells, and that a low expression at the cellular level might account for the failure of a number of tumours with a high percentage of Ki-S7-positive cells to respond to therapy. More likely, however, this lack of responsiveness is attributable to resistance mechanisms (Kellner et al, 2002) acquired during tumour progression, consistent with a lower response rate in larger tumours (Gieseler et al, 2003).

On the other hand, we found a high Ki-S7 expression indicative of an aggressive tumour phenotype in terms of higher SBR grade, hormonal receptor negativity and p53 overexpression. These observations substantiate the results of previous studies (Jarvinen et al, 1996; Rudolph et al, 1999a, b). Since wild-type p53 negatively regulates the promoter of the human TOP $2 \alpha$ gene (Sandri et al, 1996b), the immunohistochemical detection of p53, consistent with a nonfunctional protein, may be expected to be associated with high levels of Topo II $\alpha$.

Contrary to previous results from our group (Rudolph et al, 1999a) and others (Jarvinen et al, 1996, 1998; Rudolph et al, 1999b), we failed to observe a significant positive correlation between Topo II $\alpha$ expression and Her-2/neu-overexpression in this series. Approximately $50 \%$ of the Her-2/neu overexpressing tumours in our series contained high levels of Topo II $\alpha$, whereas in the remaining $50 \%$, Topo II $\alpha$ was low (Table 1 ). This finding is congruent with the results of a study by Järvinen et al (2000). In 97 breast cancers, these authors found no Topo II $\alpha$ gene copy aberrations when the Her-2/neu gene status was normal, yet when Her-2/neu was amplified, TOP $2 \alpha$ was coamplifed in $44 \%$ and deleted in $42 \%$ of the cases. Such data may explain the contradictory results of different reports analysing breast cancer susceptibility to Topo II $\alpha$ inhibitors in relation to the Her-2/neu status (Muss et al, 1994; Paik et al, 1998; Vincent-Salomon et al, 2000). In the same study, Järvinen et al (2000) observed an increased sensitivity to doxorubicin in a breast cancer cell line (UACC-812) with TOP $2 \alpha$ gene amplification and consequent protein overexpression and conversely, a decreased sensitivity to doxorubicin in a breast cancer cell line with TOP $2 \alpha$ deletion and concomitantly reduced protein content (MDA-361). In a previous study on 863 primary operable invasive ductal carcinomas with long-term follow-up (Rudolph et al, 1999a), of which only a minor proportion had been treated with Topo II $\alpha$ inhibitors, high Topo II $\alpha$ expression consequently emerged as an important independent predictor of adverse outcome next to nodal metastasis and before other classical or immunohistochemical factors, including Ki-67. However, no such correlation between Topo II $\alpha$ and survival was found in the present series. This could be attributable to a balanced effect of the Topo II $\alpha$ expression portending increased chemosensitivity to Topo II $\alpha$ inhibitors on the one hand and a higher malignant potential on the other (Kellner et al, 2002).

Primary chemotherapy in breast cancer enhances the rate of breast conservation and enables the in vivo assessment of tumour sensitivity to different chemotherapeutic drugs. Clinical decisions concerning the choice of cytotoxic therapy regimens might be improved according to the initial tumour response (Wolff and Davidson, 2000). With this in view, it would be advantageous to be able to reliably estimate tumour pathologic and biologic features beforehand in order to tailor the composition of chemotherapeutic protocols. Mindful of the fact that anthracyclines target Topo II $\alpha$, we have shown that tumours expressing high levels of Topo II $\alpha$ responded better to an anthracycline-based cytotoxic protocol than tumours with low Topo II $\alpha$ expression. Therefore, we conclude that Topo II $\alpha$ assessment may be of value for the clinical management of breast cancer in the setting of primary chemotherapy, provided that our results are corroborated by further studies.

\section{ACKNOWLEDGEMENTS}

This work was financially supported by a grant from the Rotary Club de Gradignan, France. We thank Isabelle Le Pollès for editing the manuscript.

\section{REFERENCES}

Asano T, An T, Mayes J, Zwelling LA, Kleinerman ES (1996a) Transfection of human topoisomerase II alpha into etoposide-resistant cells: transient increase in sensitivity followed by down-regulation of the endogenous gene. Biochem J 319 (Part 1): $307-313$
Asano T, An T, Zwelling LA, Takano H, Fojo AT, Kleinerman ES (1996b) Transfection of a human topoisomerase II alpha gene into etoposideresistant human breast tumour cells sensitises the cells to etoposide. Oncol Res 8: $101-110$ 
Belembaogo E, Feillel V, Chollet P, Cure H, Verrelle P, Kwiatkowski F, Achard JL, Le Bouedec G, Chassagne J, Bignon YJ (1992) Neoadjuvant chemotherapy in 126 operable breast cancers. Eur J Cancer 28A: 896-900

Berger JM, Gamblin SJ, Harrison SC, Wang JC (1996) Structure and mechanism of DNA topoisomerase II. Nature 379: 225-232

Bitran JD, Samuels B, Trujillo Y, Klein L, Schroeder L, Martinec J (1996) Her2/neu overexpression is associated with treatment failure in women with high-risk stage II and stage IIIA breast cancer ( $>10$ involved lymph nodes) treated with high-dose chemotherapy and autologous haematopoietic progenitor cell support following standard-dose adjuvant chemotherapy. Clin Cancer Res 2: 1509-1513

Clahsen PC, van de Velde, Duval C, Pallud C, Mandard AM, DelobelleDeroide A, van den Broek L, Sahmoud TM (1998) p53 protein accumulation and response to adjuvant chemotherapy in premenopausal women with node-negative early breast cancer. J Clin Oncol 16: 470-479 de Mascarel I, Soubeyran I, Mac-Grogan G, Wafflart J, Bonichon F, Durand M, Avril A, Mauriac L, Trojani M, Coindre JM (1995) Immunohistochemical analysis of estrogen receptors in 938 breast carcinomas. Concordance with biochemical assay and prognostic significance. Appl Immunohistochem 3: 222-231

Depowski PL, Rosenthal SI, Brien TP, Stylos S, Johnson RL, Ross JS (2000) Topoisomerase II alpha expression in breast cancer: correlation with outcome variables. Mod Pathol 13: $542-547$

Gieseler F, Rudolph P, Kloeppel G, Foelsch UR (2003) Resistance mechanisms of gastrointestinal malignancies - why does chemotherapy fail?. Int J Colorectal Dis, in press

Gudkov AV, Zelnick CR, Kazarov AR, Thimmapaya R, Suttle DP, Beck WT, Roninson IB (1993) Isolation of genetic suppressor elements, inducing resistance to topoisomerase II-interactive cytotoxic drugs, from human topoisomerase II cDNA. Proc Natl Acad Sci USA 90: 3231-3235

Jarvinen TA, Holli K, Kuukasjarvi T, Isola JJ (1998) Predictive value of topoisomerase II alpha and other prognostic factors for epirubicin chemotherapy in advanced breast cancer. $\mathrm{Br}$ J Cancer 77: 2267-2273

Jarvinen TA, Kononen J, Pelto-Huikko M, Isola J (1996) Expression of topoisomerase II alpha is associated with rapid cell proliferation, aneuploidy, and c-erbB2 overexpression in breast cancer. Am J Pathol 148: $2073-2082$

Jarvinen TA, Tanner M, Rantanen V, Barlund M, Borg A, Grenman S, Isola J (2000) Amplification and deletion of topoisomerase II alpha associate with ErbB-2 amplification and affect sensitivity to topoisomerase II inhibitor doxorubicin in breast cancer. Am J Pathol 156: 839-847

Kellner U, Heidebrecht HJ, Rudolph P, Biersack H, Buck F, Dakowski T, Wacker HH, Domanowski M, Seidel A, Westergaard O, Parwaresch R (1997) Detection of human topoisomerase II alpha in cell lines and tissues: characterisation of five novel monoclonal antibodies. J Histochem Cytochem 45: $251-263$

Kellner U, Sehested M, Jensen PB, Gieseler F, Rudolph P (2002) Culprit and victim - DNA topoisomerase II. Lancet Oncol 3: 235-243

MacGrogan G, Bonichon F, de Mascarel I, Trojani M, Durand M, Avril A, Coindre JM (1995) Prognostic value of p53 in breast invasive ductal carcinoma: an immunohistochemical study on 942 cases. Breast Cancer Res Treat 36: $71-81$

MacGrogan G, Mauriac L, Durand M, Bonichon F, Trojani M, de Mascarel I, Coindre JM (1996a) Primary chemotherapy in breast invasive carcinoma: predictive value of the immunohistochemical detection of hormonal receptors, p53, c-erbB-2, MiB1, pS2 and GST pi. Br J Cancer 74: $1458-1465$

MacGrogan G, Soubeyran I, de Mascarel I, Wafflart J, Bonichon F, Durand M, Avril A, Mauriac L, Trojani M, Coindre JM (1996b) Immunohistochemical detection of progesterone receptors in breast invasive ductal carcinomas. Appl Immunohistochem 4: 219-227

Mauriac L, MacGrogan G, Avril A, Durand M, Floquet A, Debled M, Dilhuydy JM, Bonichon F (1999) Neoadjuvant chemotherapy for operable breast carcinoma larger than $3 \mathrm{~cm}$ : a unicentre randomized trial with a 124-month median follow-up. Institut Bergonie Bordeaux Groupe Sein (IBBGS). Ann Oncol 10: 47-52

Muss HB, Thor AD, Berry DA, Kute T, Liu ET, Koerner F, Cirrincione CT, Budman DR, Wood WC, Barcos M (1994) c-erbB-2 expression and response to adjuvant therapy in women with node-positive early breast cancer. N Engl J Med 330: 1260-1266
Niskanen E, Blomqvist C, Franssila K, Hietanen P, Wasenius VM (1997) Predictive value of c-erbB-2, p53, cathepsin-D and histology of the primary tumour in metastatic breast cancer. Br J Cancer 76: 917-922

O’Reilly SM, Camplejohn RS, Rubens RD, Richards MA (1992) DNA flow cytometry and response to preoperative chemotherapy for primary breast cancer. Eur J Cancer 28: 681-683

Paik S, Bryant J, Park C, Fisher B, Tan-Chiu E, Hyams D, Fisher ER, Lippman ME, Wickerham DL, Wolmark N (1998) erbB-2 and response to doxorubicin in patients with axillary lymph node-positive, hormone receptor-negative breast cancer. J Natl Cancer Inst 90: 1361 - 1370

Rudolph P, MacGrogan G, Bonichon F, Frahm SO, de Mascarel I, Trojani M, Durand M, Avril A, Coindre JM, Parwaresch R (1999a) Prognostic significance of Ki-67 and topoisomerase II alpha expression in infiltrating ductal carcinoma of the breast. A multivariate analysis of 863 cases. Breast Cancer Res Treat 55: 61-71

Rudolph P, Olsson H, Bonatz G, Ratjen V, Bolte H, Baldetorp B, Ferno M, Parwaresch R, Alm P (1999b) Correlation between p53, c-erbB-2, and topoisomerase II alpha expression, DNA ploidy, hormonal receptor status and proliferation in 356 node-negative breast carcinomas: prognostic implications. J Pathol 187: 207-216

Sandri MI, Hochhauser D, Ayton P, Camplejohn RC, Whitehouse R, Turley H, Gatter K, Hickson ID, Harris AL (1996a) Differential expression of the topoisomerase II alpha and beta genes in human breast cancers. $\mathrm{Br} \mathrm{J}$ Cancer 73: $1518-1524$

Sandri MI, Isaacs RJ, Ongkeko WM, Harris AL, Hickson ID, Broggini M, Vikhanskaya F (1996b) p53 regulates the minimal promoter of the human topoisomerase II alpha gene. Nucleic Acids Res 24: 4464-4470

Slamon DJ, Leyland-Jones B, Shak S, Fuchs H, Paton V, Bajamonde A, Fleming T, Eiermann W, Wolter J, Pegram M, Baselga J, Norton L (2001) Use of chemotherapy plus a monoclonal antibody against HER2 for metastatic breast cancer that overexpresses HER2. N Engl J Med 344: 783-792

Stacey DW, Hitomi M, Chen G (2000) Influence of cell cycle and oncogene activity upon topoisomerase II alpha expression and drug toxicity. $\mathrm{Mol}$ Cell Biol 20: $9127-9137$

Tanner M, Jarvinen P, Isola J (2001) Amplification of HER-2/neu and topoisomerase II alpha in primary and metastatic breast cancer. Cancer Res 61: $5345-5348$

Tannock I (1978) Cell kinetics and chemotherapy: a critical review. Cancer Treat Rep 62: 1117-1133

Thor AD, Berry DA, Budman DR, Muss HB, Kute T, Henderson IC, Barcos M, Cirrincione C, Edgerton S, Allred C, Norton L, Liu ET (1998) erbB-2, $\mathrm{p} 53$, and efficacy of adjuvant therapy in lymph node-positive breast cancer. J Natl Cancer Inst 90: 1346-1360

Tuccari G, Rizzo A, Giuffre G, Barresi G (1993) Immunocytochemical detection of DNA topoisomerase type II in primary breast carcinomas: correlation with clinico-pathological features. Virch Arch A Pathol Anat Histopathol 423: 51-55

Vassetzky YS, Alghisi GC, Roberts E, Gasser SM (1996) Ectopic expression of inactive forms of yeast DNA topoisomerase II confers resistance to the anti-tumour drug, etoposide. Br J Cancer 73: $1201-1209$

Vincent-Salomon A, Carton M, Freneaux P, Palangie T, Beuzeboc P, Mouret E, de Cremoux P, Coue O, Zafrani B, Nicolas A, Clough K, Fourquet A, Pouillart P, Sastre-Garau X (2000) ERBB2 overexpression in breast carcinomas: no positive correlation with complete pathological response to preoperative high-dose anthracycline-based chemotherapy. Eur J Cancer 36: 586-591

Withoff S, de Vries EG, Keith WN, Nienhuis EF, van der Graaf WT, Uges DR, Mulder NH (1996a) Differential expression of DNA topoisomerase II alpha and -beta in P-gp and MRP-negative VM26, mAMSA and mitoxantrone-resistant sublines of the human SCLC cell line GLC4. $\mathrm{Br}$ J Cancer 74: 1869-1876

Withoff S, Keith WN, Knol AJ, Coutts JC, Hoare SF, Mulder NH, de Vries EG (1996b) Selection of a subpopulation with fewer DNA topoisomerase II alpha gene copies in a doxorubicin-resistant cell line panel. Br J Cancer 74: $502-507$

Wolff AC, Davidson NE (2000) Primary systemic therapy in operable breast cancer. J Clin Oncol 18: 1558-1569

Zhou Z, Zwelling LA, Kawakami Y, An T, Kobayashi K, Herzog C, Kleinerman ES (1999) Adenovirus-mediated human topoisomerase II alpha gene transfer increases the sensitivity of etoposide-resistant human breast cancer cells. Cancer Res 59: 4618-4624 